\title{
The Garment Manufacturers Risk Assessment - Swot Analysis
}

\section{Gordana Colovic *}

The College of Textile - Design, Technology and Management, Belgrade, Serbia

\section{Introduction}

Risk is defined as calculation forecast emergence of negative events (hazards) that cause loss or calculation forecast emergence of positive events (opportunities/chances), which bring us benefits [1].

Risk is a condition in which there is a possibility of negative deviations from the desired outcomes that we expect or hope will happen. In terms of business, risk is an unfulfillment of desired business objectives and it must include threats and opportunities from the environment that can potentially contribute to the growth and development of the company, but prevent development, and thus endanger the very survival of a company. The risk, in the broadest sense, is a particular danger, uncertainty, loss, or the uncertain future event that may have unintended consequences. The concept of risk comprises three elements on the Table 1.

Risk consequences on the planned garment production are [2]:

- Exceeding the framework of the assessment of production costs,

\begin{tabular}{|c|c|c|c|}
\hline Item & Elements & Chance & Time \\
\hline Risk & The perception that something might happen & Possible & Future \\
\hline Issue & Probability that something happens & Definite & Future \\
\hline Incident & The consequences of what might happen & Definite & Past \\
\hline
\end{tabular}

Table 1: The concept of risk comprises elements.

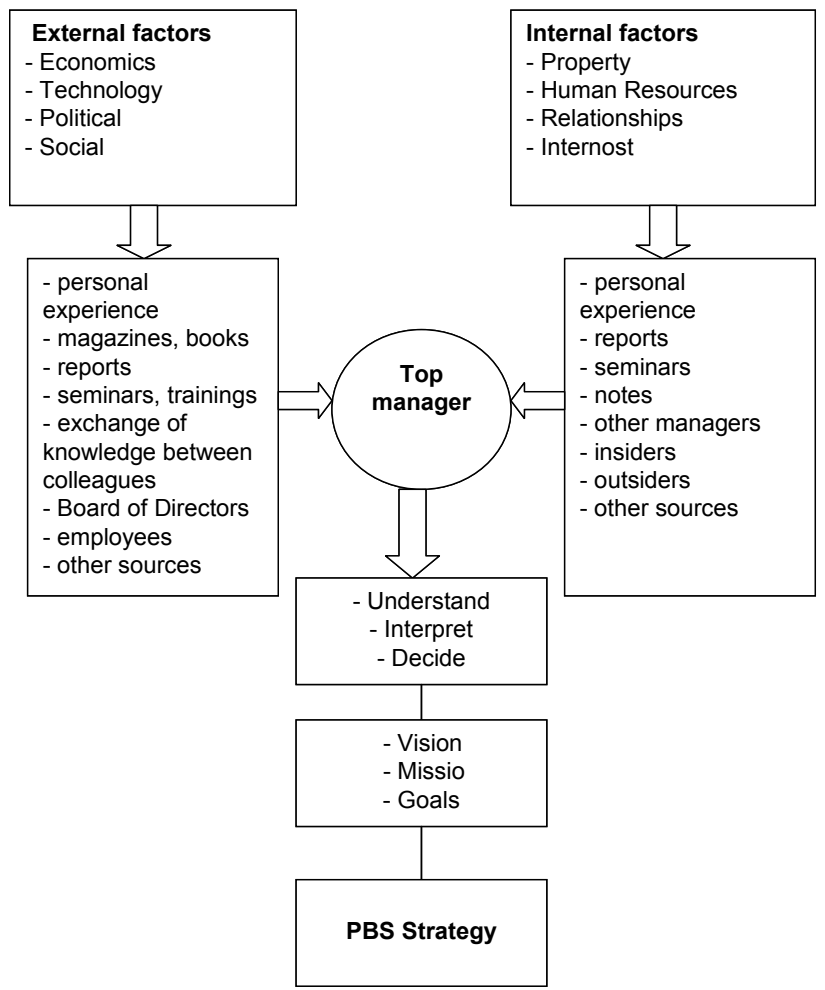

Figure 1: Production-business system (PBS) environments.
- Exceeding the requested date of making

- Not acquiring the quality of clothing.

Tracking disorders and disturbances in production, their systematization and statistical methods can lead to the sizes which belong to risk and can be included in the calculation. The risk may appear:

- Because of placement of low bids in the market and

- In production compared to the size of the series that is produced.

It is necessary to do SWOT (Strengths, Weaknesses, Opportunities and Threats) (Figure 1) analysis in order to get marketing weapon and overcome all existing problems, which means to take all advantages and eliminate weaknesses of the company. It is possible to point out solutions and consequences, as well as to show how a fashion industry should get better with the help of this analysis. SWOT analysis must be summarized, specific and to analyse key questions of each company but not ad-hoc suppositions that do not point out future actions. SWOT analysis is the method of strategic planning that enables analysis of estimates and combining of internal factors with information from external sources on the market and in business environment.

Internal estimate as well as analysis of strengths and weaknesses in garment manufacturer refers to factors that can be controlled within the organisation. That concerns not only material expenses and technicaltechnological equipment but the reputation of the firm and existing brand, innovative activities of designers' team and marketing service. While doing an internal estimate there are hindered factors such as subjectivity, lack of trust, running away from reality. Weaknesses cannot often be overcome in a short period of time.

External estimate implies those possibilities and dangers that will have a main influence on business results of a textile firm. New fashion trends, i.e. new designs that should be accepted, should also bring new results. The problem which exists in garment industry is that we analyse and follow trends that have already taken place on the fashion scene so while a collection is being accepted and the preparation for production is getting completed, a new fashion demand is here, and the old one hasn't been accustomed to yet. External estimate deals with advantages and dangers connected with a market, technology, scientific-technological development, changes in micro and macro environment, economy, ecology.

*Corresponding author: Gordana Colovic, The College of Textile - Design, Technology and Management, Belgrade, Serbia, Tel: +381 62 802005; E-mail: gordanacolovic@gmail.com

Received November 07, 2014; Accepted November 09, 2014; Published November 11, 2014

Citation: Colovic G (2014) The Garment Manufacturers Risk Assessment - Swot Analysis. J Textile Sci Eng 4: 173. doi:10.4172/2165-8064.1000173

Copyright: () 2014 Colovic $\mathrm{G}$. This is an open-access article distributed under the terms of the Creative Commons Attribution License, which permits unrestricted use, distribution, and reproduction in any medium, provided the original author and source are credited. 


\begin{tabular}{|c|c|c|}
\hline & Actual & Potential \\
\hline Upside/Positive & $\begin{array}{l}\text { STRENGTHS } \\
\text { - Tradition in business } \\
\text { - Futuristic design } \\
\text { - Good image } \\
\text { - Reaction to a new fashion trend } \\
\text { - Quality of textile fabric and production } \\
\text { - New ergonomic form of production model } \\
\text { - Short period of development of a model and } \\
\text { short period of duration } \\
\text { - Industrial training conducted by specialist } \\
\text { - Establishing "show room" objects } \\
\text { - Ecological requirements }\end{array}$ & $\begin{array}{l}\text { WEAKNESSES } \\
\text { - Very high price because of fast changes } \\
\text { - Small series with a large number of models (three } \\
\text { to five articles in work order) } \\
\text { - Manufacturing of only three sizes } \\
\text { - Bad covering of foreign market } \\
\text { - High price of energy } \\
\text { - Condition and price rise of raw material because of } \\
\text { introducing VAT } \\
\text { - Short time for optimal of products }\end{array}$ \\
\hline Downside/Negative & $\begin{array}{l}\text { OPPORTUNITIES } \\
\text { - Consumers' wish for new designs } \\
\text { - Marketing of products into a new market } \\
\text { - Making e-mail catalogue } \\
\text { - Value of labour } \\
\text { - Production of garments Made-to-Measure } \\
\text { - Promote technology transfer and knowledge } \\
\text { - Cooperation with educational institutions }\end{array}$ & $\begin{array}{l}\text { THREATS } \\
\text { - Import of similar articles of clothing at low prices } \\
\text { - Competitors have lower price } \\
\text { - Competitors have better distribution net with more } \\
\text { sales places } \\
\text { - Quick obsolesce of technology } \\
\text { - Labor market rigidities } \\
\text { - Lack of skilled personnel }\end{array}$ \\
\hline
\end{tabular}

Figure 2: The SWOT analyses for Ramax company.

There comes the case when one textile firm, depending on its ability to follow fashion trend "blindly", sees the production of the very upto-date design as advantage, whereas the other textile firm that has e.g. classical brand in clothing sees the same fashion trend and a new design as danger [1].

Within a fashion company, paying special attention to the problems of designing a new product, it is necessary to observe within internal estimate first of all skills, training, attitude of marketing team, fashion designer and technologist and then the production management structure of the company itself (Figure 2), current systems (CAD/ CAM systems), relations and communications among people. In order to manufacture an adequate product real expenses must be estimated, especially textile fabrics and quality of manufacturing garments, in order to lengthen a life cycle of a fashion product and not to neglect technical-technological capacities of the firm. The rhythm of technological development is faster than the development of human generation (life time for technological generation is four to five years, which is seven to eight times less than an engineer's length of service in clothing industry), so permanent training of production-technical employees is necessary.

Within an external estimate, when analysing possibilities and dangers of a fashion product that should be designed and redesigned in accordance with a fashion trend, it is necessary to study the very situation on the market, to determine target groups and categories of consumers. Garment manufacturers who do not invest in the development of products and production technology get into danger and can't "keep pace" with fashion trend although they try hard. A good distribution net, besides placing goods on the home market, should think of doing it on the foreign market. Because of poor economic power and large competition on the world market there are possibilities for many fashion companies to fail, therefore a good distribution net should enable joint breakthrough for many fashion companies to the foreign market, as the only real possibility [3].

\section{References}

1. Paunovic D, Colovic G (2005) The application of SWOT analysis in designing of garments. Management 37: 71-77.

2. Colovic G (2012) Strategic management in the garment industry, Woodhead Publishing, India.

3. McNamee PB (1985) Tools and Techniques for Strategic Management. 